\title{
Searching if SARS-CoV-2 Subsists Following the Disinfection of Potable Water
}

\author{
Djamel Ghernaout ${ }^{1,2}$, Noureddine Elboughdiri1,3 \\ ${ }^{1}$ Chemical Engineering Department, College of Engineering, University of Ha'il, Ha'il, Saudi Arabia \\ ${ }^{2}$ Chemical Engineering Department, Faculty of Engineering, University of Blida, Blida, Algeria \\ ${ }^{3}$ Chemical Engineering Process Department, National School of Engineering, University of Gabes, Gabes, \\ Tunisia \\ Email: ^djamel_andalus@hotmail.com
}

How to cite this paper: Ghernaout, D. and Elboughdiri, N. (2021) Searching if SARSCoV-2 Subsists Following the Disinfection of Potable Water. Open Access Library Journal, 8: e7505.

https://doi.org/10.4236/oalib.1107505

Received: May 8, 2021

Accepted: June 5, 2021

Published: June 8, 2021

Copyright $\odot 2021$ by author(s) and Open Access Library Inc.

This work is licensed under the Creative Commons Attribution International License (CC BY 4.0).

http://creativecommons.org/licenses/by/4.0/

\begin{abstract}
The manifestation of severe acute respiratory syndrome coronavirus 2 (SARSCoV-2) in water and wastewater has newly been revealed. The stools and masks of the patients diagnosed with coronavirus disease (COVID-19) were viewed as the key way of $\mathrm{CoV}$ diffusion into aquatic medium. Most $\mathrm{CoV}$ kinds that attack human (likely for SARS-CoV-2) are frequently demobilized quickly in water (the endurance of human $\mathrm{CoV} 229 \mathrm{E}$ in water being 7 days at $23^{\circ} \mathrm{C}$ ). Nevertheless, the endurance time of $\mathrm{CoV}$ in water strongly follows temperature, characteristics of water, concentration of suspended solids and organic matter, solution $\mathrm{pH}$, and dose of disinfectant injected. The present disinfection technique of potable water can efficiently demobilize most of the bacterial and viral communities existing in water, particularly SARS-CoV-2 (more vulnerable to killing agent such as free chlorine). Scientists affirmed that SARS-CoV-2 RNA was observed in inflow wastewater and not found in outflow one. Even if the occurrence of SARS-CoV-2 in water influents has been affirmed, a fundamental interrogation is whether it could remain alive or contaminate following the disinfection method of potable water. Until now, only one study asserted that the infectivity of SARS-CoV-2 in water for persons was null founded on the absence of cytopathic effect in infectivity tests. Thus, more researches must be dedicated to the survival of SARS-CoV-2 in water and wastewater below various working circumstances (temperature and water matrix) and whether the diffusion from COVID-19-infected water to human is an emerging anxiety.
\end{abstract}

\section{Subject Areas}

Chemical Engineering \& Technology 


\section{Keywords}

Coronaviruses (CoVs), Severe Acute Respiratory Syndrome Coronavirus-2 (SARS-CoV-2), SARS-CoV-2 Stability, Disinfection, Microorganisms (MOs), Wastewater Treatment Plants (WWTPs)

\section{Introduction}

A sudden epidemic eruption of coronavirus disease 2019 (COVID-19), emerged from severe acute respiratory syndrome coronavirus (SARS-CoV), has presently provoked huge worldwide anxieties [1] [2] [3]. The causative agent of such pandemic was forever called SARS-CoV-2 (temporarily baptized 2019-nCOV) to differentiate it from the SARS-CoV-1 virus that was initially perceived in 2002 [4] [5] [6]. Researchers [7] discovered lately that the SARS-CoV-2 was associated with Malayan pangolins (Manis javanica) in China. Therefore, the pangolins were holding responsible as a likely halfway host in the arrival of COVID-19 eruption in humans. Other scientists [8] reached an identical deduction affirming that the pangolin species is an innate recipient of SARS-CoV-2-like coronavirus.

Comparable to the Middle East respiratory syndrome coronavirus (MERS-CoV; recognized in 2012), the SARS-CoV-1 and SARS-CoV-2 viruses mostly spread out of the small respiratory droplets of disease carriers produced from sneezing and coughing by humans [1]. This way is known as human-to-human propagation [9] or respiratory propagation [10]. Therefore super spreaders (SARS-CoV-2) are able to quickly transfer the contagion to numerous others, mainly out of usual international travel or mass meetings in public spaces. Even if the faecal-oral diffusion of SARS-CoV-2 is conceivable [10] [11] [12], there are not any observational information or solid confirmations to set the faecal-oral supposition. In fact, three types of coronavirus (MERS-CoV, SARS-CoV-1, and SARSCoV-2) are identical in terms of their biochemical and physical characteristics [4] [5] [13] and categorized as enveloped viruses that hold the bits of protein and genetic material surrounded by a lipid host cell membrane [9]. As a result, in a measure, foregoing investigations on SARS-CoV-1 and MERS-CoV coronavirus and different enveloped viruses are able to present an approaching information for SARS-CoV-2 [14].

Lately, nucleic acid pieces of SARS-CoV-2 coronavirus have been observed in extracted sludge from wastewater treatment plants (WWTPs) [1] [15] [16], municipal sewage [17] [18] [19] or wastewater [20] [21] [22], medical wastewater [2] [8] [23], wastewater from commercial cruise ship and commercial passenger aircraft [1], non-potable water [1], secondary-treated wastewater [20] [24] [25], and river water [20] [26]. Therefore, additional studies remain requested in such direction [4] [27] [28]. So as to evaluate the efficiency of wastewater treatment 
methods for the actual pandemic catastrophe, this review is dedicated to the next fundamental interrogations: 1 ) what the transmission routes of the SARS-CoV-2 coronavirus into sewage or wastewater are, and 2) whether $\mathrm{CoV}$ can survive after drinking water disinfection process.

\section{Diffusion Way of SARS-CoV-2 into Water and Wastewater}

Since 2013, for the CoV-contaminated communities living in apartment buildings, wastewater plumbing systems (WPSs) have been viewed as a likely passage for transporting the SARS-CoV-1 coronavirus into the sewer system [1] [29] [30]. Identical to SARS-CoV-1, the SARS-CoV-2 virus may be disseminated by means of aerosols or microscopic water droplets [31] [32] [33]. Indeed, scientists [14] mentioned that the SARS-CoV-2 and SARS-CoV-1 viruses are identical in their persistence in aerosols and on surfaces. Following the inoculum shed, the viruses are able to stay viable and contagious on surfaces (until a few days) and in aerosols (for hours). Likewise, researchers [34] examined the survival of SARS-CoV-2 in air, surface, and personal protective equipment of disease carriers and healthcare workers. They noticed that the samples collected from air outlet fans, door handles, sinks, and toilet bowls were positive. Such findings prove that SARS-CoV-2 could be transferred via the stools of contaminated people. Moreover, scientists [35] gathered the high-touch surface samples of a quarantine room and discovered that the percentage of gathered samples was positive for SARS-CoV-2 as follows: $70 \%$ (in the bedroom) $>50 \%$ (bathroom) $>$ $33 \%$ (corridor). The most infected sites with the highest viral loads were identified at the inner walls of the toilet bowl and the sewer inlet of the room [35]. Such a diffusion passage, through the WPS, might be likely in charge of environmental pollution and propagation of COVID-19 in the communities (Figure 1). Consequently, researchers [29] lately furnished many advices to guarantee that propagation via the WPS is reduced. Figure 2 outlines some worthy propositions to avert the danger of diffusing the microorganisms (MOs) via WPS in the buildings.

Investigations proved that the stool specimens gathered from contracted patients (comprising asymptomatic children) had the SARS-CoV-2 virus [36] [37] [38]. This is due to the presence of COVID-19 contagion in the gastrointestinal tract of patients and could be excreted from the gastrointestinal tract via their faeces [1] [39]. Such fact proposed that the SARS-CoV-2 virus is mostly excreted in the stools of a contaminated human. Lately, scientists established that the median lifespan of SARS-CoV-2 in the stool specimens of the patients was up to 22 days [40], which was longer than that of SARS-CoV-1 (only 4 days) [41]. These scientists as well depicted that SARS-CoV-2 is able to survive longer in the stool specimens (22 days, 17 - 31 days) than that in respiratory (18 days, 13 - 29 days) and serum (16 days, 11 - 21 days) ones [40]. Broadly, the faeces and urine from some COVID-19-infected patients are discharged into sewer systems and subsequently enter WWTPs [17] [42]. This could be viewed as the key way of 


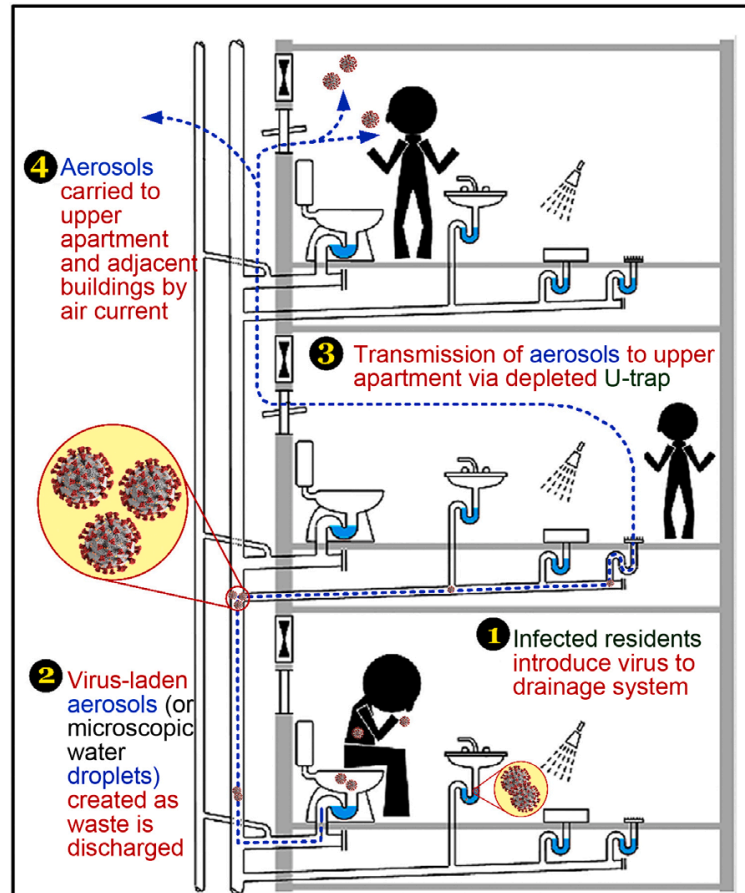

The virus was finally discharged into the sewer system

Figure 1. A diffusion pathway of SARS-CoV-1 virus (likely for SARS-CoV-2 virus) at the buildings via the wastewater plumbing system (WPS) [1].

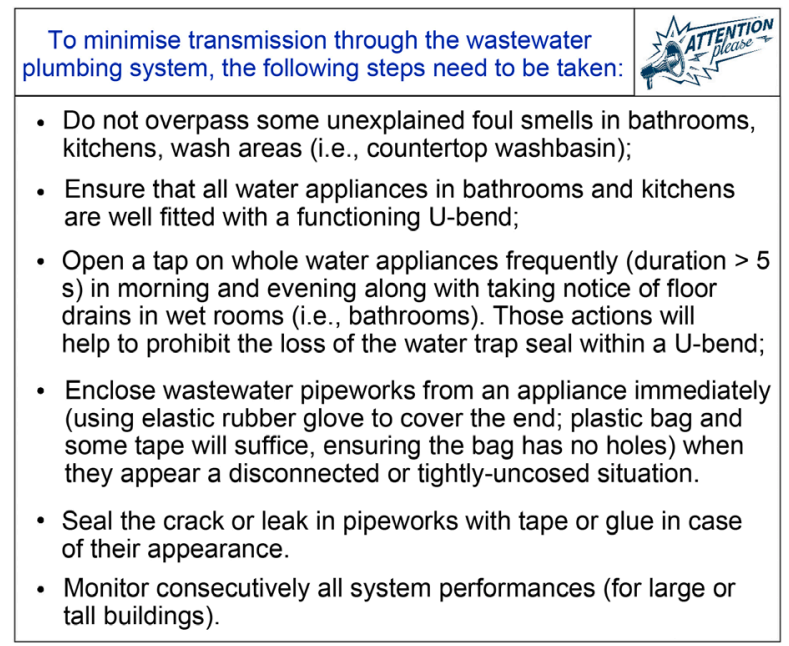

Figure 2. Propositions to reduce the pathogens diffusion via the wastewater plumbing system (WPS) in the building [1].

SARS-CoV-2 diffusion to water and wastewater [4] [42] since SARS-CoV is able to keep its contagious potential in the tool specimens for $>7$ days at $20^{\circ} \mathrm{C}$ [41]. Schematic way of propagation for the SARS-CoV-2 virus is illustrated in Figure 3 [1].

Since the fresh COVID-19 pandemic provokes severe respiratory illness and related causalities, persons are constantly persuaded or demanded to follow a 


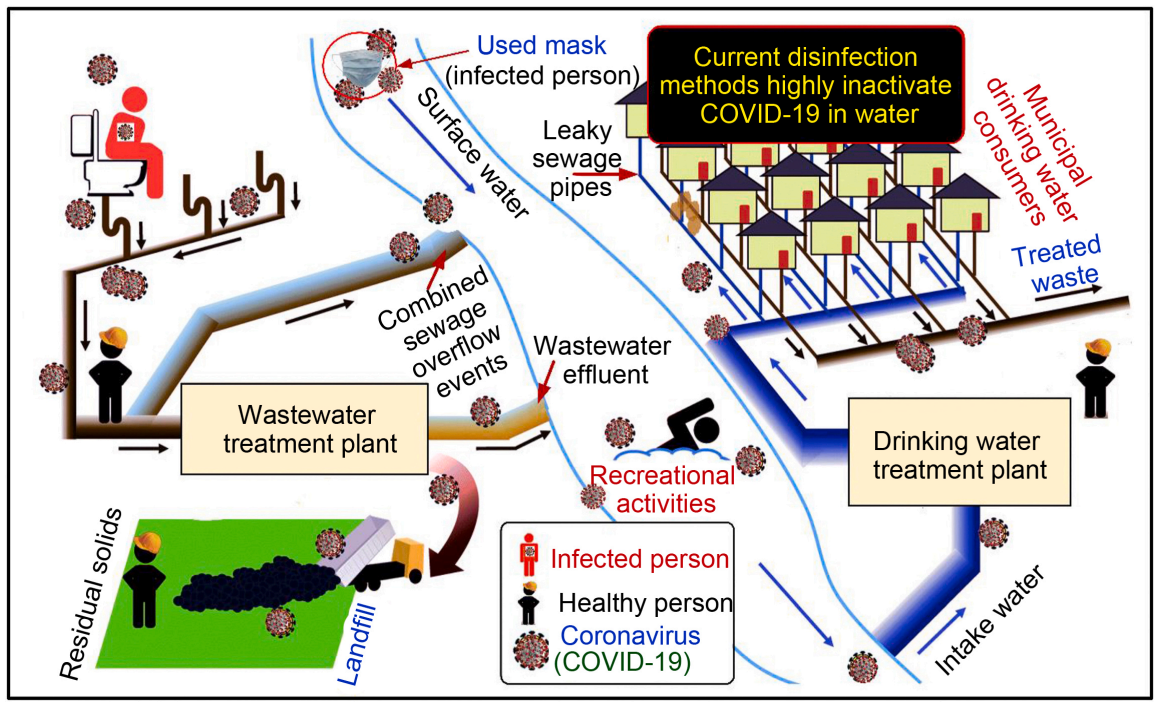

Figure 3. A route of transmission for SARS-CoV-2 [1].

compulsory policy to wear face masks in public areas as a precaution against the diffusion and contagion of SARS-CoV-2 [43] [44] [45]. Ho et al. [46] observed that there was no big distinction between the commercial surgical mask and self-designed triple-layer cotton mask for blocking droplets during coughing. Thus, cotton masks could serve as an encouraging substitute for medical surgical in stopping the diffusion of respiratory droplets in micro-environments [46]. Leung et al. [31] proved that surgical face masks could ban the direct propagation of influenza viruses and human $\mathrm{CoV}$ s from the virus-borne airborne particles, droplets, and body fluids of infected persons. On the other hand, researchers [47] deduced that "surgical and cotton masks seem to be ineffective in preventing the dissemination of SARS-CoV-2 from the coughs of patients with COVID-19 to the environment and external mask surface" [1]. Nonetheless, this investigation has been withdrawn as demanded by the editor [48] since their explication of exploratory findings was confusing. Surprisingly, scientists [49] mentioned that the SARS-CoV-2 virus could yet remain at an identifiable degree of contagion on the outer film of a surgical face mask for up to a week. Consequently, handling thrown face masks that may constitute a very possible propagation way of SARS-CoV-2 into water should be accorded primacy for examination. This is particularly significant since none of the masks utilized are gathered and treated as poisonous wastes [1]. Scholars [50] noticed that some of them may have been thrown away or disposed carelessly into the surface water. The occurrence of $\mathrm{CoV}$-carrying masks discarded into water could form an additional diffusion route (Figure 3), even if more investigations have to work on this hypothesis [1].

As aforesaid, one of the propagation courses of COVID-19 into water and wastewater is via the huge quantity of face masks employed throughout the globe by general public, patients and health workers [1]. After their usage, those face masks have been disposed without treatment or disinfection, therefore rais- 
ing worries concerning the possible health hazards and threatening to the nature. Numerous techniques have been suggested to disinfect the utilized masks for reusing or before disposing to diminish the poisonous wastes [45] [51] [52] [53]. As an illustration, researcher [51] proposed to employ the microwave technology for sanitizing the disposable medical and utilized cloth masks. Such process implies an antiseptic solution (i.e., 0.9\% physiological saline) being sprayed on the mask to keep the moisture. The moist mask was thereafter transferred into a microwave oven with a default capacity of $800 \mathrm{~W}$ and then heated during $1 \mathrm{~min}$. Such disinfection procedure has been observed to efficiently eliminate $99.9 \%$ of viruses [51].

For disinfecting the surgical face masks and N95 respirators employed, an additional physical process (dry heat pasteurization) has been newly noted by scientists [53]. Six species of respiratory bacteria (Escherichia coli, Staphylococcus aureus, Pseudomonas aeruginosa, Klebsiella pneumonia, Acinetobacter baumannii, and Corynebacterium pseudodiphtheria), one fungi species (Candida albicans), and one H1N1 indicator virus (an RNA-enveloped virus identical to SARS-CoV-2) were chosen as target pathogens. Xiang et al. [53] deduced that the dry heat of utilized surgical face masks and $\mathrm{N} 95$ respirators at $70^{\circ} \mathrm{C}$ for $1 \mathrm{~h}$ in an electric oven could warrant the efficient disinfection of them. The sterile masks and respirators could be consecutively employed at least three rounds of the heating without considerably modifying their filtering performances and physical properties [53].

Li et al. [52] observed that a shorter steam treatment is an efficacious technique for the quick decontamination of methicillin-resistant $S$. aureus and bacteriophage MS2 on the surface of the N95 respirators and medical face masks. The inoculated N95 respirators and medical masks were placed into a steamer $\left(100^{\circ} \mathrm{C}\right)$ for various steam periods of 2,10 , or $30 \mathrm{~s}$. They noted that the steam periods of 10 and $30 \mathrm{~s}$ were enough for decontaminating $S$. aureus and bacteriophage MS2 on both respirators and medical masks, while the opposite was true for the 2-s steam treatment. Nevertheless, the technique of steam treatment did not efficiently decontaminate Geobacillu stearothermophilus spores in the surface of respirators and medical face masks [1].

\section{Search If SARS-CoV-2 Lives Following the Disinfection Process of Potable Water}

Scholars affirmed that there are no at hand proofs affirming the endurance of SARS-CoV-2 virus following the disinfection method for both wastewater and potable water [1] [54]. Lately, scientists [55] gathered wastewater samples from the County Wastewater Treatment Plant and examined whether SARS-CoV-2 virus is tracked in the samples. They depicted that the RNA gene fragments of the SARS-CoV-2 virus were not observed in the treated wastewater.

As a rule, there are two groups of virus: enveloped virus and non-enveloped virus (large and small non-enveloped viruses) [1] [56]. SARS-CoV-2 is a typical 
enveloped virus (surrounded by a fragile outer lipid membrane) that has been acknowledged as the easiest virus to be neutralized when comparing with large or small non-enveloped virus [1] [57]. Due to the fact that the MERS-CoV and SARS-CoV-1 viruses are derived from the same family of the SARS-CoV-2 coronaviruses, they present identical biochemical and physical characteristics. Thus, to a certain degree, they could be viewed as a typical example.

Among the present techniques (i.e., adsorption, ozonation [58], chlorination [59] [60] [61], membrane, ultraviolet (UV) light [62] [63], and advanced oxidation processes [64] [65] [66]) that are utilized for demobilizing CoVs [67] or enveloped viruses [1], the UV radiation and chlorination remain the most frequent processes employed for disinfecting water supplies [1] [68] [69]. Investigators [70] used chlorine dioxide $\left(\mathrm{ClO}_{2}\right)$ and sodium hypochlorite $(\mathrm{NaClO})$ as the target disinfectants to examine the demobilization of SARS-CoV-1 in wastewater. They discovered that SARS-CoV-1 was so vulnerable to the selective disinfectants; even if both of them could neutralize SARS-CoV-1 virus in water, $\mathrm{NaClO}$ was better than $\mathrm{ClO}_{2}$ in terms of killing [70]. For instance, in the identical low-concentration disinfectants $(10 \mathrm{mg} / \mathrm{L})$, the rates of SARS-CoV-1 neutralization utilizing $\mathrm{ClO}_{2}$ and $\mathrm{NaClO}$ were observed to be $99.99 \%$ and $68.38 \%$, respectively after $10 \mathrm{~min}$ of contact period. Nonetheless, below the identical empirical circumstances, both disinfectants were less efficient in eliminating $E$. coli with the small demobilization rates of $17.4 \%$ for $\mathrm{ClO}_{2}$ and $14.3 \%$ for $\mathrm{NaClO}$. Such finding proved that SARS-CoV-1 coronavirus was more sensible to disinfectants than E. coli [70] [71] [72]. As a consequence, the treated water was found to be safe for humans [1] [73].

Lately, researchers [8] examined the demobilization of SARS-CoV-2 in medical wastewater from the septic tanks of the Fangcang hospital by $\mathrm{NaOCl}$. They noticed that injecting free chlorine $>0.5 \mathrm{mg} / \mathrm{L}$ (residence period of $90 \mathrm{~min}$ ) could not guarantee a total disinfection of the SARS-CoV-2 virus in medical wastewaters, while the opposite was correct for employing $6700 \mathrm{~g} / \mathrm{m}^{3}$ dosage of $\mathrm{NaOCl}$. Even if the SARS-CoV-2 viral RNA was not observed inside the over-dosage of $\mathrm{NaOCl}$ employed, an elevated degree of disinfection by-product residuals could provoke many hazards to natural system and menaces to human health [1] [8] [74].

Figure 4 depicts the disinfection performance of different MOs in water using chemical disinfectant (chlorination) and non-chemical disinfectant (UV light) [1]. Obviously, non-enveloped viruses (poliovirus, Coxsackievirus, and Rotavirus) could be demobilized by two techniques. Minutely, non-enveloped viruses are able to be killed at a chlorine dose $(C \times t)$ of less than $15 \mathrm{mg} \times \mathrm{min} / \mathrm{L}$. Consequently, it is anticipated that the enveloped SARS-CoV-2 virus will be efficiently demobilized by chlorination even at a lower chlorine $C \times t$ dose of $15 \mathrm{mg} \times$ $\mathrm{min} / \mathrm{L}$ [1]. In like manner, Ye et al. [75] proved that enveloped viruses (Pseudomonas virus $\varphi 6$ ) were more vulnerable than non-enveloped viruses (i.e., bacteriophage MS2) under free chlorine disinfection (prepared from $\mathrm{NaClO}$ ) and 


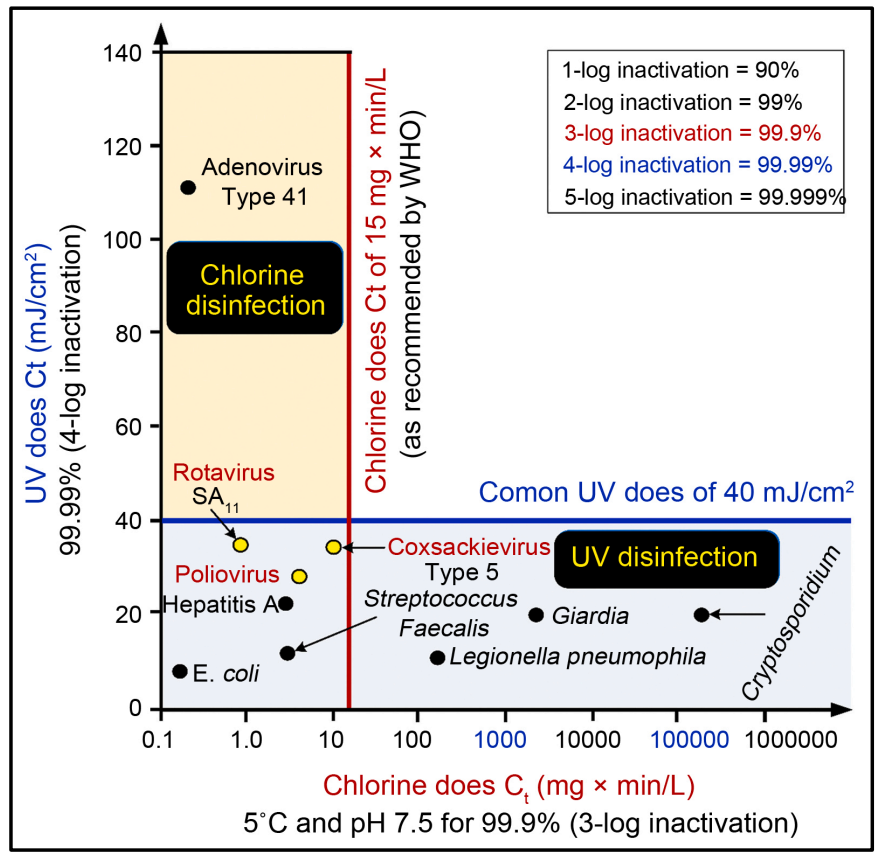

Figure 4. Synergistic utilization of the common disinfection systems: UV (ultra-violet) light and chlorination [1].

$\mathrm{UV}$ radiation at $254 \mathrm{~nm}\left(\mathrm{UV}_{254}\right)$. In a similar fashion, scientists [1] observed that H5N1 (an enveloped virus) was very sensible to UV radiation ( $>5.5$-log inactivation reached within a low UV fluence of $25 \mathrm{~mJ} / \mathrm{cm}^{2}$ ); however, the opposite was correct for bacteriophage MS2 (1.87-log inactivation). Despite the fact that each disinfection process is efficacious for killing the enveloped virus (as well for SARS-CoV-2), the integration of these techniques is constantly advised [1]. This is due to the fact that chlorination-based disinfection is not efficacious in neutralizing protozoan parasites (i.e., Cryptosporidium), while the opposite is correct for UV light-based disinfection (Figure 4).

In particular, scientists newly affirmed that the RNA of SARS-CoV-2 virus was observed in untreated wastewaters in WWTP such as influents [76] [77] and secondary-treated water samples [1] [76]. Nevertheless, its RNA was not found in tertiary effluent samples of WWTPs following the present disinfection method with alone $\mathrm{NaClO}$ [76], the inetegration of $\mathrm{NaClO}$ and $\mathrm{UV}$ [76], peracetic acid [76], or high intensity UV lamps [77]. Even if the present disinfection method from WWTPs in Spain [76] and Italy [77] neutralized completely SARSCoV-2 virus, the scientists did not mention the explained circumstances of the disinfection method (i.e., the employed disinfectant injection and residence period) and the impacts of such circumstances on the survival of such CoV [76] [77].

Membrane technology has been largely utilized as a traditional disinfection technique for potable water [78] [79] [80]. In such technology, the size of the viruses has a crucial contribution in choosing the suitable types of membranes [81] [82] [83]. Each virion (particle) of CoVs (i.e., SARS-CoV-1 and MERS-CoV 
related to the Coronaviridae family in the Nidovirales order) ranged from $80 \mathrm{~nm}$ to $220 \mathrm{~nm}$ in diameter [1]. Newly, scientists [5] noted that the diameter of SARS-CoV-2 virion varied from $60 \mathrm{~nm}$ to $140 \mathrm{~nm}$ [13], which is identical to that of SARS-CoV-1 (from 80 to $140 \mathrm{~nm}$ ) [84]. Figure 5 presents a juxtaposition of MOs' sizes with the pore sizes of the membranes. Following the diameter of each SARS-CoV-2 virion and membranes, it is decidedly advised that the ultrafiltration (UF), nanofiltration (NF), and reverse osmosis (RO) membranes are convenient for demobilizing (or throwing away) the CoVs in SARS-CoV-2-infected water [5].

Relating to adsorption process, investigators [85] proposed the biopolymeric material (i.e., the cations-modified chitosan-based nano/microspheres) and used it for the selective and reversible adsorption of different CoVs from aqueous suspensions. The target CoVs comprised two human CoVs (HCoV-NL63 and HCoV-OC43) and mouse hepatitis coronavirus (MHV). They proved that the biopolymeric material is able to adsorb the HCoV-NL63 (strongly) and MHV (moderately) CoV from water, but cannot adsorb HCoV-OC43 coronavirus. The desorption investigation employing $2.0 \mathrm{M} \mathrm{NaCl}$ depicted that the desorbed HCoV-NL63 coronavirus could be desorbed from the laden biopolymeric material. The number of viral RNA copies that was desorbed from the laden biopolymeric material was $2.4 \pm 0.9 \times 106$ (copies/mL). Impressively, the HCoV-NL63 particles desorbed were still contagious (i.e., the retention of virus virulence) [85] [86]. Nonetheless, whether the biopolymeric material could efficiently adsorb SARS-CoV-2 coronavirus in water is an actual dare that must be confirmed by more examinations [1] [87] [88].

To recap, even if until this moment, there is no proof on the survival of SARS-CoV-2 virus in treated water, more investigations stay to be performed to minutely accept such hypothesis [1] [89] [90]. As mentioned above, the treatment

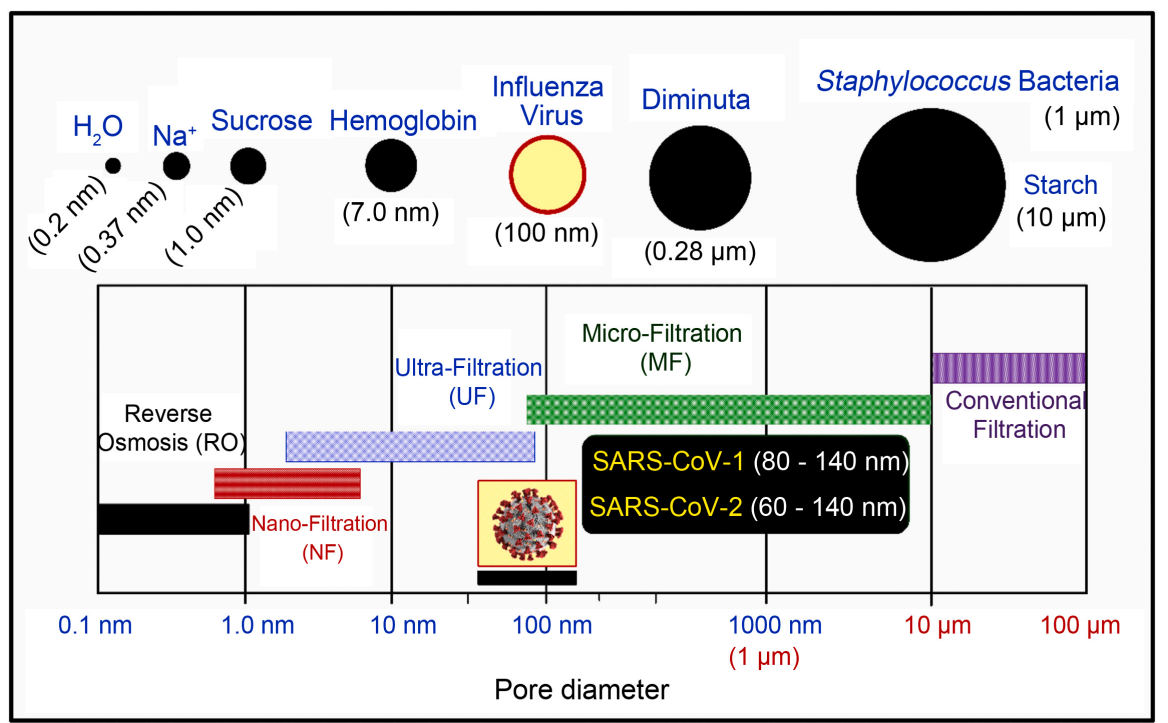

Figure 5. Juxtaposition of microorganisms (MOs) sizes comprising SARS-CoV-1 [84] and SARS-CoV-2 [5] coronaviruses with the pore size diameters of membranes [1]. 
technologies of running disinfection might be enough to neutralize SARS-CoV-2 in water [91] [92] [93]. Nevertheless, the protocols for disinfecting the SARS$\mathrm{CoV}-2$ virus in potable water treatment are missing [94] [95].

\section{Conclusions}

This review disclosed that until now, even if the presence of SARS-CoV-2 coronavirus in river water and untreated wastewater is proved, a firm proof of its survival time in water ecosystems remains absent. Additional investigations have to be dedicated to robustly assert the survival time of SARS-CoV-2 coronavirus in different water circumstances (temperature, $\mathrm{pH}$, organic matter, etc.) as well as its infectivity. The running disinfection technologies might be sufficient to effectively kill SARS-CoV-2 in water. The procedures for disinfecting SARSCoV-2 virus must be defined by the pertinent scientific communities. The manifestation of fresh SARS-CoV-2 coronavirus in water and wastewater is very potential as mentioned throughout the globe. Nearly all CoVs are vulnerable to temperature and are fast demobilized in water. The most prevalent diffusion way of SARSCoV-2 into water, sewage, and wastewater is via stools of symptomatic persons. Actual disinfection techniques applied in the potable water treatment efficiently demobilize and effectively demolish SARS-CoV-2 in water. Periodic observation of wastewater could furnish an early warning medium for the apparition of the SARS-CoV-2 coronavirus in a population, which leads to reducing the pathogen propagation [1].

Researches have proved that SARS-CoV-2 coronavirus has been observed in river water, sewage, and wastewater samples; however, the danger produced to humans and the nature is low. The stability of the virus is as well insignificant and mainly gets demolished in the ambient temperature and climatic circumstances. Nonetheless, the presence and distribution of the virus in WWTPs help us to determine the source and location that people are being touched [1].

\section{Acknowledgements}

The Research Deanship of University of Ha'il, Saudi Arabia, has funded this research through the Project RG-20 113.

\section{Conflicts of Interest}

The authors declare no conflicts of interest regarding the publication of this paper.

\section{References}

[1] Tran, H.N., Le, G.T., Nguyen, D.T., Juang, R.-S., Rinklebe, J., Bhatnagar, A., Lima, E.C., Iqbal, H.M.N., Sarmah, A.K. and Chao, H.-P. (2021) SARS-CoV-2 Coronavirus in Water and Wastewater: A Critical Review about Presence and Concern. Environmental Research, 193, Article ID: 110265.

https://doi.org/10.1016/j.envres.2020.110265

[2] Ghernaout, D. and Elboughdiri, N. (2020) Urgent Proposals for Disinfecting Hos- 
pital Wastewaters during COVID-19 Pandemic. Open Access Library Journal, 7, e6373. https://doi.org/10.4236/oalib.1106373

[3] Ghernaout, D. and Ghernaout, B. (2020) Controlling COVID-19 Pandemic through Wastewater Monitoring. Open Access Library Journal, 7, e6411.

https://doi.org/10.4236/oalib.1106411

[4] Chaudhry, A.K. and Sachdeva, P. (2020) Coronavirus Disease 2019 (COVID-19): A New Challenge in Untreated Wastewater. Canadian Journal of Civil Engineering, 47, 1005-1009. https://doi.org/10.1139/cjce-2020-0240

[5] Zhu, N., Zhang, D., Wang, W., Li., X., Yang, B., Song, J., Zhao, X., Huang, B., Shi, W., Lu, R., Niu, P., Zhan, F., Ma, X., Wang, D., Xu, W., Wu, G., Gao, G.F. and Tan, W. (2020) A Novel Coronavirus from Patients with Pneumonia in China, 2019. The New England Journal of Medicine, 382, 727-733.

https://doi.org/10.1056/NEJMoa2001017

[6] Ghernaout, D. and Elboughdiri, N. (2020) Environmental Engineering for Stopping Viruses Pandemics. Open Access Library Journal, 7, e6299.

https://doi.org/10.4236/oalib.1106299

[7] Lam, T.T.-Y., Jia, N., Zhang, Y.-W., Shum, M.H.-H., Jiang, J.-F., Zhu, H.-C., Tong, Y.-G., Shi, Y.-X., Ni, X.-B., Liao, Y.-S., Li, W.-J., Jiang, B.-G., Wei, W., Yuan, T.-T., Zheng, K., Cui, X.-M., Li, J., Pei, G.-Q., Qiang, X., Cheung, W.Y.-M., Li, L.-F., Sun, F.-F., Qin, S., Huang, J.-C., Leung, G.M, Holmes, E.C., Hu, Y.-L., Guan, Y. and Cao, W.-C. (2020) Identifying SARS-CoV-2 Related Coronaviruses in Malayan Pangolins. Nature, 583, 282-285. https://doi.org/10.1038/s41586-020-2169-0

[8] Zhang, T., Wu, Q. and Zhang, Z. (2020) Probable Pangolin Origin of SARS-CoV-2 Associated with the COVID-19 Outbreak. Current Biology, 30, 1346-1351.

https://doi.org/10.1016/j.cub.2020.03.022

[9] Chan, J.F.-W., Yuan, S., Kok, K.-H., To, K.K.-W., Chu, H., Yang, J., Xing, F., Liu, J., Yip, C.C.-Y., Poon, R.W.-S., Tsoi, H.-W., Lo, S.K.-F., Chan, K.-H., Poon, V.K.-M., Chan, W.-M., Ip, J.D., Cai, J.-P., Cheng, V.C.-C., Chen, H., Hui, C.K.-M. and Yuen, K.-Y. (2020) A Familial Cluster of Pneumonia Associated with the 2019 Novel Coronavirus Indicating Person-to-Person Transmission: A Study of a Family Cluster. The Lancet, 395, 514-523. https://doi.org/10.1016/S0140-6736(20)30154-9

[10] Wu, Y., Guo, C., Tang, L., Hong, Z., Zhou, J., Dong, X., Yin, H., Xiao, Q., Tang, Y., Qu, X., Kuang, L., Fang, X., Mishra, N., Lu, J., Shan, H., Jiang, G. and Huang, X. (2020) Prolonged Presence of SARS-CoV-2 Viral RNA in Faecal Samples. The Lancet: Gastroenterology and Hepatology, 5, 434-435. https://doi.org/10.1016/S2468-1253(20)30083-2

[11] Arslan, M., Xu, B. and Gamal El-Din, M. (2020) Transmission of SARS-CoV-2 via Fecal-Oral and Aerosols-Borne Routes: Environmental Dynamics and Implications for Wastewater Management in Underprivileged Societies. Science of the Total Environment, 743, Article ID: 140709. https://doi.org/10.1016/j.scitotenv.2020.140709

[12] Heller, L., Mota, C.R. and Greco, D.B. (2020) COVID-19 Faecal-Oral Transmission: Are We Asking the Right Questions? Science of the Total Environment, 729, Article ID: 138919. https://doi.org/10.1016/j.scitotenv.2020.138919

[13] Race, M., Ferraro, A., Galdiero, E., Guida, M., Núñez-Delgado, A., Pirozzi, F., Siciliano, A. and Fabbricino, M. (2020) Current Emerging SARS-CoV-2 Pandemic: Potential Direct/Indirect Negative Impacts of Virus Persistence and Related Therapeutic Drugs on the Aquatic Compartments. Environmental Research, 188, Article ID: 109808. https://doi.org/10.1016/j.envres.2020.109808

[14] van Doremalen, N., Bushmaker, T., Morris, D.H, Holbrook, M.G., Gamble, A., Wil- 
liamson, B.N., Tamin, A., Harcourt, J.L., Thornburg, N.J., Gerber, S.I., LloydSmith, J.O., de Wit, E. and Munster, V.J. (2020) Aerosol and Surface Stability of SARS-CoV-2 as Compared with SARS-CoV-1. The New England Journal of Medicine, 382, 1564-1567. https://doi.org/10.1056/NEJMc2004973

[15] Ghernaout, D., Elboughdiri, N. and Ghareba, S. (2020) Fenton Technology for Wastewater Treatment: Dares and Trends. Open Access Library Journal, 7, e6045. https://doi.org/10.4236/oalib.1106045

[16] Ghernaout, D. and Elboughdiri, N. (2020) On the Treatment Trains for Municipal Wastewater Reuse for Irrigation. Open Access Library Journal, 7, e6088. https://doi.org/10.4236/oalib.1106088

[17] Ahmed, W., Angel, N., Edson, J., Bibby, K., Bivins, A., O’Brien, J.W., Choi, P.M., Kitajima, M., Simpson, S.L., Li, J., Tscharke, B., Verhagen, R., Smith, W.J.M., Zaugg, J., Dierens, L., Hugenholtz, P., Thomas, K.V. and Mueller, J.F. (2020) First Confirmed Detection of SARS-CoV-2 in Untreated Wastewater in Australia: A Proof of Concept for the Wastewater Surveillance of COVID-19 in the Community. Science of the Total Environment, 728, Article ID: 138764. https://doi.org/10.1016/j.scitotenv.2020.138764

[18] Medema, G., Heijnen, L., Elsinga, G., Italiaander, R. and Brouwer, A. (2020) Presence of SARS-Coronavirus-2 RNA in Sewage and Correlation with Reported COVID-19 Prevalence in the Early Stage of the Epidemic in the Netherlands. Environmental Science and Technology Letters, 7, 511-516. https://doi.org/10.1021/acs.estlett.0c00357

[19] Ghernaout, D. and Elboughdiri, N. (2020) Advanced Oxidation Processes for Wastewater Treatment: Facts and Future Trends. Open Access Library Journal, 7, e6139. https://doi.org/10.4236/oalib.1106139

[20] Haramoto, E., Malla, B., Thakali, O. and Kitajima, M. (2020) First Environmental Surveillance for the Presence of SARS-CoV-2 RNA in Wastewater and River Water in Japan. Science of the Total Environment, 737, Article ID: 140405. https://doi.org/10.1016/j.scitotenv.2020.140405

[21] Ghernaout, D. and Elboughdiri, N. (2020) Domestic Wastewater Treatment: Difficulties and Reasons, and Prospective Solutions-China as an Example. Open Access Library Journal, 7, e6141.

[22] Ghernaout, D. (2018) Increasing Trends towards Drinking Water Reclamation from Treated Wastewater. World Journal of Applied Chemistry, 3, 1-9. https://doi.org/10.11648/j.wjac.20180301.11

[23] Ghernaout, D. (2013) The Best Available Technology of Water/Wastewater Treatment and Seawater Desalination: Simulation of the Open Sky Seawater Distillation. Green and Sustainable Chemistry, 3, 68-88. https://doi.org/10.4236/gsc.2013.32012

[24] Ghernaout, D., Alshammari, Y. and Alghamdi, A. (2018) Improving Energetically Operational Procedures in Wastewater Treatment Plants. International Journal of Advanced and Applied Sciences, 5, 64-72. https://doi.org/10.21833/ijaas.2018.09.010

[25] Al Arni, S., Amous, J. and Ghernaout, D. (2019) On the Perspective of Applying of a New Method for Wastewater Treatment Technology: Modification of the Third Traditional Stage with Two Units, One by Cultivating Microalgae and Another by Solar Vaporization. International Journal of Environmental Sciences and Natural Resources, 16, Article ID: 555934. https://doi.org/10.19080/IJESNR.2019.16.555934

[26] Guerrero-Latorre, L., Ballesteros, I., Villacrés-Granda, I., Granda, M.G., FreirePaspuel, B. and Ríos-Touma, B. (2020) SARS-CoV-2 in River Water: Implications in Low Sanitation Countries. Science of the Total Environment, 743, Article ID: 
140832. https://doi.org/10.1016/j.scitotenv.2020.140832

[27] Ghernaout, D. (2019) Reviviscence of Biological Wastewater Treatment-A Review. Applied Engineering, 3, 46-55.

[28] Ghernaout, D. and Elboughdiri, N. (2019) Upgrading Wastewater Treatment Plant to Obtain Drinking Water. Open Access Library Journal, 6, e5959. https://doi.org/10.4236/oalib.1105959

[29] Gormley, M., Aspray, T.J., Kelly, D.A. and Rodriguez-Gil, C. (2017) Pathogen Cross-Transmission via Building Sanitary Plumbing Systems in a Full Scale Pilot Test-Rig. PloS ONE, 12, e0171556. https://doi.org/10.1371/journal.pone.0171556

[30] McKinney, K.R., Gong, Y.Y. and Lewis, T.G. (2006) Environmental Transmission of SARS at Amoy Gardens. Journal of Environmental Health, 68, 26-30.

[31] Leung, N.H.L., Chu, D.K.W., Shiu, E.Y.C., Chan, K.-H., McDevitt, J.J., Hau, B.J.P., Yen, H.-L., Li, Y., Ip, D.K.M., Peiris, J.S.M., Seto, W.-H., Leung, G.M., Milton, D.K. and Cowling, B.J. (2020) Respiratory Virus Shedding in Exhaled Breath and Efficacy of Face Masks. Nature Medicine, 26, 676-680. https://doi.org/10.1038/s41591-020-0843-2

[32] Ghernaout, D. and Elboughdiri, N. (2020) On the Other Side of Viruses in the Background of Water Disinfection. Open Access Library Journal, 7, e6374. https://doi.org/10.4236/oalib.1106374

[33] Ghernaout, D. (2020) Water Treatment Challenges towards Viruses Removal. Open Access Library Journal, 7, e6408. https://doi.org/10.4236/oalib.1106408

[34] Ong, S.W.X., Tan, Y.K., Chia, P.Y., Lee, T.H., Ng, O.T., Wong, M.S.Y. and Marimuthu, K. (2020) Air, Surface Environmental, and Personal Protective Equipment Contamination by Severe Acute Respiratory Syndrome Coronavirus 2 (SARS$\mathrm{CoV}-2$ ) from a Symptomatic Patient. The Journal of the American Medical Association, 323, 1610-1612. https://doi.org/10.1001/jama.2020.3227

[35] Hu, X., Xing, Y., Ni, W., Zhang, F., Lu, S., Wang, Z., Gao, R. and Jiang, F. (2020) Environmental Contamination by SARS-CoV-2 of an Imported Case during Incubation Period. Science of the Total Environment, 742, Article ID: 140620. https://doi.org/10.1016/j.scitotenv.2020.140620

[36] Holshue, M.L., DeBolt, C., Lindquist, S., Lofy, K.H., Wiesman, J., Bruce, H., Spitters, C., Ericson, K., Wilkerson, S., Tural, A., Diaz, G., Cohn, A., Fox, L., Patel, A., Gerber, S.I., Kim, L., Tong, S., Lu, X., Lindstrom, S., Pallansch, M.A., Weldon, W.C., Biggs, H.M., Uyeki, T.M. and Pillai, S.K. (2020) First Case of 2019 Novel Coronavirus in the United States. The New England Journal of Medicine, 382, 929-936. https://doi.org/10.1056/NEJMoa2001191

[37] Tang, A., Tong, Z., Wang, H., Dai, Y., Li, K., Liu, J., Wu, W., Yuan, C., Yu, M., Li, P. and Yan, J. (2020) Detection of Novel Coronavirus by RT-PCR in Stool Specimen from Asymptomatic Child, China. Emerging Infectious Diseases, 26, 1337-1339. https://doi.org/10.3201/eid2606.200301

[38] Wang, W., Xu, Y., Gao, R., Lu, R., Han, K., Wu, G. and Tan, W. (2020) Detection of SARS-CoV-2 in Different Types of Clinical Specimens. The Journal of the American Medical Association, 323, 1843-1844. https://doi.org/10.1001/jama.2020.3786

[39] Xiao, F., Tang, M., Zheng, X., Liu, Y., Li, X. and Shan, H. (2020) Evidence for Gastrointestinal Infection of SARS-CoV-2. Gastroenterology, 158, 1831-1833. https://doi.org/10.1053/j.gastro.2020.02.055

[40] Zheng, S., Fan, J., Yu, F., Feng, B., Lou, B., Zou, Q., Xie, G., Lin, S., Wang, R., Yang, X., Chen, W., Wang, Q., Zhang, D., Liu, Y., Gong, R., Ma, Z., Lu, S., Xiao, Y., Gu, Y., Zhang, J., Yao, H., Xu, K., Lu, X., Wei, G., Zhou, J., Fang, Q., Cai, H., Qiu, Y., 
Sheng, J., Chen, Y. and Liang, T. (2020) Viral Load Dynamics and Disease Severity in Patients Infected with SARS-CoV-2 in Zhejiang Province, China, January-March 2020: Retrospective Cohort Study. British Medical Journal, 369, m1443. https://doi.org/10.1136/bmj.m1443

[41] Lai, M.Y.Y., Cheng, P.K.C. and Lim, W.W.L. (2005) Survival of Severe Acute Respiratory Syndrome Coronavirus. Clinical Infectious Diseases, 41, e67-e71. https://doi.org/10.1086/433186

[42] Collivignarelli, M.C., Collivignarelli, C., Miino, M.C., Abbà, A., Pedrazzani, R. and Bertanza, G. (2020) SARS-CoV-2 in Sewer Systems and Connected Facilities. Process Safety and Environmental Protection, 143, 196-203. https://doi.org/10.1016/j.psep.2020.06.049

[43] Ghernaout, D. and Elboughdiri, N. (2020) Disinfecting Water: Plasma Discharge for Removing Coronaviruses. Open Access Library Journal, 7, e6314.

https://doi.org/10.4236/oalib.1106314

[44] Feng, S., Shen, C., Xia, N., Song, W., Fan, M. and Cowling, B.J. (2020) Rational Use of Face Masks in the COVID-19 Pandemic. The Lancet: Respiratory Medicine, 8, 434-436. https://doi.org/10.1016/S2213-2600(20)30134-X

[45] Liu, Y., Leachman, S.A. and Bar, A. (2020) Proposed Approach for Reusing Surgical Masks in COVID-19 Pandemic. Journal of the American Academy of Dermatology, 83, e53-e54. https://doi.org/10.1016/j.jaad.2020.04.099

[46] Ho, K.-F., Lin, L.-Y., Weng, S.-P. and Chuang, K.-J. (2020) Medical Mask versus Cotton Mask for Preventing Respiratory Droplet Transmission in Micro Environments. Science of the Total Environment, 735, Article ID: 139510.

https://doi.org/10.1016/j.scitotenv.2020.139510

[47] Bae, S., Kim, M.C., Kim, J.Y., Cha, H.H., Lim, J.S., Jung, J., Kim, M.J., Oh, D.K., Lee, M.K., Choi, S.H., Sung, M., Hong, S.B., Chung, J.W. and Kim, S.H. (2020) Effectiveness of Surgical and Cotton Masks in Blocking SARS-CoV-2: A Controlled Comparison in 4 Patients. Annals of Internal Medicine, 173, M20-1342. https://doi.org/10.7326/M20-1342

[48] Bae, S., Kim, M.C., Kim, J.Y., Cha, H.H., Lim, J.S., Jung, J., Kim, M.J., Oh, D.K., Lee, M.K., Choi, S.H., Sung, M., Hong, S.B., Chung, J.W. and Kim, S.H. (2020) Notice of Retraction: Effectiveness of Surgical and Cotton Masks in Blocking SARS-CoV-2. Annals of Internal Medicine, 173, 79. https://doi.org/10.7326/L20-0745

[49] Chin, A.W.H., Chu, J.T.S., Perera, M.R.A., Hui, K.P.Y., Yen, H.-L., Chan, M.C.W., Peiris, M. and Poon, L.L.M. (2020) Stability of SARS-CoV-2 in Different Environmental Conditions. The Lancet: Microbe, 1, E10. https://doi.org/10.1016/S2666-5247(20)30003-3

[50] Kalina, M. and Tilley, E. (2020) "This Is Our Next Problem": Cleaning up from the COVID-19 Response. Waste Management, 108, 202-205.

https://doi.org/10.1016/j.wasman.2020.05.006

[51] Doan, H.N. (2020) Medical Face Masks Can Be Reused with Microwave Method: Expert.

https://vietnamnews.vn/society/654072/medical-face-masks-can-be-reused-with-mi crowave-method-expert.html

[52] Li, D.F., Cadnum, J.L., Redmond, S.N., Jones, L.D., Pearlmutter, B., Haq, M.F. and Donskey, C.J. (2020) Steam Treatment for Rapid Decontamination of N95 Respirators and Medical Face Masks. American Journal of Infection Control, 48, 855-857. https://doi.org/10.1016/j.ajic.2020.05.009

[53] Xiang, Y., Song, Q. and Gu, W. (2020) Decontamination of Surgical Face Masks and 
N95 Respirators by Dry Heat Pasteurization for One Hour at $70^{\circ} \mathrm{C}$. American Journal of Infection Control, 48, 880-882. https://doi.org/10.1016/j.ajic.2020.05.026

[54] Sherchan, S.P., Shahin, S., Ward, L.M., Tandukar, S., Aw, T.G., Schmitz, B., Ahmed, W. and Kitajima, M. (2020) First Detection of SARS-CoV-2 RNA in Wastewater in North America: A Study in Louisiana, USA. Science of the Total Environment, 743, Article ID: 140621. https://doi.org/10.1016/j.scitotenv.2020.140621

[55] Pineda, P. (2020) ASU, UA Researchers Look for Traces of COVID-19 in Tempe and Tucson Wastewater.

https://www.azcentral.com/story/news/local/tempe/2020/04/02/asu-researchers-loo k-traces-covid-19-tempe-wastewater-could-be-early-warning-system/5109746002/

[56] Ghernaout, D., Elboughdiri, N. and Al Arni, S. (2020) New Insights towards Disinfecting Viruses-Short Notes. Journal of Water Reuse and Desalination, 10, 173-186. https://doi.org/10.2166/wrd.2020.050

[57] Ghernaout, D. and Elboughdiri, N. (2021) Modeling Viruses' Isoelectric Points as a Milestone in Intensifying the Electrocoagulation Process for Their Elimination. Open Access Library Journal, 8, e7166. https://doi.org/10.4236/oalib.1107166

[58] Ghernaout, D. and Elboughdiri, N. (2020) Towards Enhancing Ozone Diffusion for Water Disinfection-Short Notes. Open Access Library Journal, 7, e6253. https://doi.org/10.4236/oalib.1106253

[59] Ghernaout, D., Moulay, S., Ait Messaoudene, N., Aichouni, M., Naceur, M.W. and Boucherit, A. (2014) Coagulation and Chlorination of NOM and Algae in Water Treatment: A Review. International Journal of Environmental Monitoring and Analysis, 2, 23-34. https://doi.org/10.11648/j.ijema.s.2014020601.14

[60] Ghernaout, D. (2017) Water Treatment Chlorination: An Updated Mechanistic Insight Review. Chemistry Research Journal, 2, 125-138.

[61] Irki, S., Ghernaout, D., Naceur, M.W., Alghamdi, A. and Aichouni, M. (2018) Decolorization of Methyl Orange (MO) by Electrocoagulation (EC) Using Iron Electrodes under a Magnetic Field (MF). II. Effect of Connection Mode. World Journal of Applied Chemistry, 3, 56-64. https://doi.org/10.11648/j.wjac.20180302.13

[62] Ghernaout, D. and Elboughdiri, N. (2020) UV-C/ $/ \mathrm{H}_{2} \mathrm{O}_{2}$ and Sunlight $/ \mathrm{H}_{2} \mathrm{O}_{2}$ in the Core of the Best Available Technologies for Dealing with Present Dares in Domestic Wastewater Reuse. Open Access Library Journal, 7, e6161. https://doi.org/10.4236/oalib.1106161

[63] Ghernaout, D. and Elboughdiri, N. (2020) Vacuum-UV Radiation at $185 \mathrm{~nm}$ for Disinfecting Water. Chemical Science and Engineering Research, 2, 12-17.

https://doi.org/10.36686/Ariviyal.CSER.2020.02.04.015

[64] Ghernaout, D. (2013) Advanced Oxidation Phenomena in Electrocoagulation Process: A Myth or a Reality? Desalination and Water Treatment, 51, 7536-7554. https://doi.org/10.1080/19443994.2013.792520

[65] Ghernaout, D. (2019) Virus Removal by Electrocoagulation and Electrooxidation: New Findings and Future Trends. Journal of Environmental Science and Allied Research, 85-90. https://doi.org/10.29199/2637-7063/ESAR-202024

[66] Ghernaout, D. (2019) Electrocoagulation and Electrooxidation for Disinfecting Water: New Breakthroughs and Implied Mechanisms. Applied Engineering, 3, 125-133.

[67] Naddeo, V. and Liu, H. (2020) Editorial Perspectives: 2019 Novel Coronavirus (SARS-CoV-2): What Is Its Fate in Urban Water Cycle and How Can the Water Research Community Respond? Environmental Science. Water Research and Technology, 6, 1213-1216. https://doi.org/10.1039/D0EW90015J 
[68] Ghernaout, D. and Elboughdiri, N. (2020) Is Not It Time to Stop Using Chlorine for Treating Water? Open Access Library Journal, 7, e6007.

[69] Ghernaout, D., Naceur, M.W. and Aouabed, A. (2011) On the Dependence of Chlorine By-Products Generated Species Formation of the Electrode Material and Applied Charge during Electrochemical Water Treatment. Desalination, 270, 9-22. https://doi.org/10.1016/j.desal.2011.01.010

[70] Wang, X.-W., Li, J.-S., Jin, M., Zhen, B., Kong, Q.-X., Song, N., Xiao, W.-J., Yin, J., Wei, W., Wang, G.-J., Si, B.-Y., Guo, B.-Z., Liu, C., Ou, G.-R., Wang, M.-N., Fang, T.-Y., Chao, F.-H. and Li, J.-W. (2005) Study on the Resistance of Severe Acute Respiratory Syndrome-Associated Coronavirus. Journal of Virology Methods, 126, 171-177. https://doi.org/10.1016/j.jviromet.2005.02.005

[71] Ghernaout, D., Badis, A., Ghernaout, B. and Kellil, A. (2008) Application of Electrocoagulation in Escherichia Coli Culture and Two Surface Waters. Desalination, 219, 118-125. https://doi.org/10.1016/j.desal.2007.05.010

[72] Belhout, D., Ghernaout, D., Djezzar-Douakh, S. and Kellil, A. (2010) Electrocoagulation of a Raw Water of Ghrib Dam (Algeria) in Batch Using Aluminium and Iron Electrodes. Desalination and Water Treatment, 16, 1-9.

https://doi.org/10.5004/dwt.2010.1081

[73] Ghernaout, D. and Ghernaout, B. (2010) From Chemical Disinfection to Electrodisinfection: The Obligatory Itinerary? Desalination and Water Treatment, 16, 156-175. https://doi.org/10.5004/dwt.2010.1085

[74] Chu, W., Fang, C., Deng, Y. and Xu, Z. (2021) Intensified Disinfection Amid COVID-19 Pandemic Poses Potential Risks to Water Quality and Safety. Environmental Science and Technology, 55, 4084-4086.

https://doi.org/10.1021/acs.est.0c04394

[75] Ye, Y., Chang, P.H., Hartert, J. and Wigginton, K.R. (2018) Reactivity of Enveloped Virus Genome, Proteins, and Lipids with Free Chlorine and $\mathrm{UV}_{254}$. Environmental Science and Technology, 52, 7698-7708. https://doi.org/10.1021/acs.est.8b00824

[76] Randazzo, W., Truchado, P., Cuevas-Ferrando, E., Simón, P., Allende, A. and Sánchez, G. (2020) SARS-CoV-2 RNA in Wastewater Anticipated COVID-19 Occurrence in a Low Prevalence Area. Water Research, 181, Article ID: 115942. https://doi.org/10.1016/j.watres.2020.115942

[77] Rimoldi, S.G., Stefani, F., Gigantiello, A., Polesello, S., Comandatore, F., Mileto, D., Maresca, M., Longobardi, C., Mancon, A., Romeri, F., Pagani, C., Cappelli, F., Roscioli, C., Moja, L., Gismondo, M.R. and Salerno, F. (2020) Presence and Infectivity of SARS-CoV-2 Virus in Wastewaters and Rivers. Science of the Total Environment, 744, Article ID: 140911. https://doi.org/10.1016/j.scitotenv.2020.140911

[78] Bodzek, M., Konieczny, K. and Rajca, M. (2019) Membranes in Water and Wastewater Disinfection-Review. Archives of Environmental Protection, 45, 3-18.

[79] Ghernaout, D. (2020) New Configurations and Techniques for Controlling Membrane Bioreactor (MBR) Fouling. Open Access Library Journal, 7, e6579.

[80] Khan, M.I., Shanableh, A., Elboughdiri, N., Kriaa, K., Ghernaout, D., Ghareba, S., Khraisheh, M. and Lashari, M.H. (2021) Higher Acid Recovery Efficiency of Novel Functionalized Inorganic/Organic Composite Anion Exchange Membranes from Acidic Wastewater. Membranes, 11, 133.

https://doi.org/10.3390/membranes11020133

[81] Ghernaout, D. and El-Wakil, A. (2017) Short Communication: Requiring Reverse Osmosis Membranes Modifications-An Overview. American Journal of Chemical Engineering, 5, 81-88. https://doi.org/10.11648/j.ajche.20170504.15 
[82] Ghernaout, D. (2017) Reverse Osmosis Process Membranes Modeling-A Historical Overview. Journal of Civil, Construction and Environmental Engineering, 2, 112-122.

[83] Ghernaout, D., El-Wakil, A., Alghamdi, A., Elboughdiri, N. and Mahjoubi, A. (2018) Membrane Post-Synthesis Modifications and How It Came about. International Journal of Advanced and Applied Sciences, 5, 60-64.

https://doi.org/10.21833/ijaas.2018.02.010

[84] Ksiazek, T.G., Erdman, D., Goldsmith, C.S., Zaki, S.R., Peret, T., Emery, S., Tong, S., Urbani, C., Comer, J.A., Lim, W., Rollin, P.E., Dowell, S.F., Ling, A.-E., Humphrey, C.D., Shieh, W.-J., Guarner, J., Paddock, C.D., Rota, P., Fields, B., DeRisi, J., Yang, J.-Y., Cox, N., Hughes, J.M., LeDuc, J.W., Bellini, W.J. and Anderson, L.J. (2003) A Novel Coronavirus Associated with Severe Acute Respiratory Syndrome. The New England Journal of Medicine, 348, 1953-1966.

https://doi.org/10.1056/NEJMoa030781

[85] Ciejka, J., Wolski, K., Nowakowska, M., Pyrc, K. and Szczubiałka, K. (2017) Biopolymeric Nano/Microspheres for Selective and Reversible Adsorption of Coronaviruses. Materials Science and Engineering. $C$, 76, 735-742.

https://doi.org/10.1016/j.msec.2017.03.047

[86] Ghernaout, D. (2017) Microorganisms' Electrochemical Disinfection Phenomena. EC Microbiology, 9, 160-169.

[87] Ghernaout, D. (2020) Electric Field (EF) in the Core of the Electrochemical (EC) Disinfection. Open Access Library Journal, 7, e6587.

[88] Ghernaout, D., Ghernaout, B. and Naceur, M.W. (2011) Embodying the Chemical Water Treatment in the Green Chemistry-A Review. Desalination, 271, 1-10. https://doi.org/10.1016/j.desal.2011.01.032

[89] Ghernaout, D. and Naceur, M.W. (2011) Ferrate (VI): In Situ Generation and Water Treatment-A Review. Desalination and Water Treatment, 30, 319-332. https://doi.org/10.5004/dwt.2011.2217

[90] Boucherit, A., Moulay, S., Ghernaout, D., Ibraheem, A., Ghernaout, A.-G.B., Naceur, M.W., Ait Messaoudene, N., Aichouni, M., Mahjoubi, A.A. and Elboughdiri, N.A. (2015) New Trends in Disinfection By-Products Formation upon Water Treatment. Journal of Research and Developments in Chemistry, 2015, Article ID: 628833.

[91] Ghernaout, D. (2017) Environmental Principles in the Holy Koran and the Sayings of the Prophet Muhammad. American Journal of Environmental Protection, 6, 75-79. https://doi.org/10.11648/j.ajep.20170603.13

[92] Ghernaout, D. (2017) Water Reuse (WR): The Ultimate and Vital Solution for Water Supply Issues. International Journal of Sustainable Development Research, 3, 36-46. https://doi.org/10.11648/j.ijsdr.20170304.12

[93] Ghernaout, D. (2018) Magnetic Field Generation in the Water Treatment Perspectives: An Overview. International Journal of Advanced and Applied Sciences, 5, 193-203. https://doi.org/10.21833/ijaas.2018.01.025

[94] Ghernaout, D. (2018) Disinfection and DBPs Removal in Drinking Water Treatment: A Perspective for a Green Technology. International Journal of Advanced and Applied Sciences, 5, 108-117. https://doi.org/10.21833/ijaas.2018.02.018

[95] Ghernaout, D., Aichouni, M. and Alghamdi, A. (2018) Applying Big Data in Water Treatment Industry: A New Era of Advance. International Journal of Advanced and Applied Sciences, 5, 89-97. https://doi.org/10.21833/ijaas.2018.03.013 